\title{
Testing Optimal Seigniorage Theory in Taiwan, 1965-2012
}

\author{
Ming-Hung Yao and Shiou-Yen Chu
}

\begin{abstract}
The optimal collection of taxes and seigniorage is an important issue in public finance. For developing and emerging countries, seigniorage is particularly essential to provide an additional source for government revenue. Barro (1979) and Mankiw(1987) propose tax-smoothing and revenue-smoothing hypotheses to discuss how the government should optimally collect taxes. This paper aims to test the taxand revenue-smoothing hypotheses with Taiwaneseannual data from 1965 to 2012. Unit root tests and Johansen's cointegration technique are employed. Our results indicate that Taiwanese data are in favor of these two hypotheses. The government may have used seignorage as a supplement to raise tax revenue. Moreover, both fiscal policy and monetary policy are implemented in an optimal fashion to finance government expenditure.
\end{abstract}

Index Terms-Cointegration analysis, optimal seigniorage theory, tax smoothing, revenue smoothing.

\section{INTRODUCTION}

The optimal collection of taxes and seigniorage is an important issue in public finance. Seigniorage generally is regarded as an inflation tax. The government issues new currency, increases the price level and redistributes the wealth from the lender to the borrower. The higher the inflation rate, the more revenue the government receives from seigniorage. For developing and emerging countries, seigniorage is particularly important to provide an additional source for government revenue.

Barro (1979) [1] and Mankiw(1987) [2] propose tax-smoothing and revenue-smoothing hypotheses to discuss how the government should optimally collect taxes. Barroassumes that the government smoothes the tax rates in different time periods to minimize the distortion, which is defined as the present value of excess burdens. The optimality conditions state that tax collections should follow a random walk.Mankiw proposes that the optimal tax rates are positively associated with inflation and nominal interest rates. More specifically, inflation rates, nominal interest rates, and optimal tax rates follow a random walk.

The tax smoothing theory implies that when the government anticipates an increase in future spending, it should reduce current budget deficit and accumulate more savings. On the other hand, if the government expects a decrease in future spending, it should increase current budget deficits. The government should issue debts to finance a temporary and substantial increase in government spending.

Manuscript received December 13, 2013; revised March 31, 2014.

Ming-Hung Yao is with the Department of Wealth and Taxation Management, National Kaohsiung University of Applied Sciences, 80778 Taiwan (e-mail: mhyao@kuas.edu.tw).

Shiou-Yen Chu is with the Department of Economics, National Chung Cheng University, 62102 Taiwan (e-mail: ecdsyc@ccu.edu.tw).
The U.S. data from year 1917 to 1976 and from year 1985 to 1985 were empirically investigated in Barro's and Mankiw's original models, respectively. The ordinary least squares results in both models are in accord with the hypotheses. Huang and Lin (1993) [3] reexamine Barro's tax smoothing hypothesis using annual U.S. fiscal data from year 1929 to 1988 . They employ log-linearization on government expenditure, budget deficit, and aggregate output. Then, a vector autoregression (VAR) framework is used to test the linear relation. Their results indicate that the post-1947 data support the tax smoothing hypothesis. Serletis and Schorn (1999) [4] conduct cointegration tests, unit root tests and a VAR approach on quarterly data of Canada, France, the UK and the US. The empirical evidences of these four countries support tax- and inflation-smoothing, but not revenue-smoothing hypotheses. Ricciuti (2001) [5] tests these two hypotheses using Italian data from 1861 to1998. He defines seigniorage as the ratios of changing monetary base of the Treasury overGDP fromprevious period. Besides standard unit-root tests, a Granger causality analysis and a VAR approach are also implemented. The findings include that a unit root exists in tax rates, but not in seigniorage. Doğru (2013) [6] applies cointegration and vector error correction methods techniques to Turkish data. He finds that a causality relationship from inflation and tax revenue to nominal interest rates exists in the long run, but not in the short run.

This paper employs Johansen's cointegration technique [7] to test Barro's tax-smoothing hypothesis and Mankiw's revenue-smoothing hypothesis with Taiwanese annual data. We find that Taiwanese data support these two hypotheses. Next section will describe the basic model. Section III provides empirical results and Section IV concludes.

\section{BASIC MODEL}

In Barro's (1978) model, government expenditure is assumed to be exogenous. Seigniorage is combined with other government tax revenue. The government aims to minimize the tax distortion defined as (1) with respect to $\left\{T_{t}, B_{t+1}\right\}_{t=0}^{\infty}$ subject to a budget constraint (2).

$$
\begin{array}{r}
E_{t} \sum_{i=0}^{\infty} \beta^{i} L\left(T_{t+i}, Y_{t+i}\right) \\
B_{t+1}=(1+r) B_{t}+G_{t}-T_{t}
\end{array}
$$

where $Y_{t}$ is the national income at time $t, T_{t}$ is the total tax revenue at time $t, B_{t}$ is the interest-bearing government debt at time $t, G_{t}$ is the exogenous real government expenditure, $L$ is the loss function, $(1+r)$ is the gross real interest rate, 
$\beta$ is the discount factor.

Combined with the non-Ponzi-game condition (3), equation (2) can be written as the intertemporal budget constraint (4).

$$
\begin{gathered}
\lim _{t \rightarrow \infty} \frac{B_{t}}{(1+r)^{t}}=0 \\
\sum_{i=0}^{\infty} \frac{1}{(1+r)^{i}} E_{t} T_{t+i}=B_{t}+\sum_{i=0}^{\infty} \frac{1}{(1+r)^{i}} E_{t} G_{t+i}
\end{gathered}
$$

The Euler equations are obtained as follows.

$$
L^{\prime}\left(T_{t}\right)=(1+r) \beta E_{t} L^{\prime}\left(T_{t+1}\right)
$$

As $\beta=1 /(1+r)$, equation (5) becomes

$$
\begin{gathered}
L^{\prime}\left(T_{t}\right)=E_{t} L^{\prime}\left(T_{t+1}\right) \\
T_{t}=E_{t} T_{t+1}
\end{gathered}
$$

Equation (6) implies that the excess burden from raising tax revenue should be equalized in different periods. If a quadratic loss function is used, equation (6) also implies (7). The collection of tax revenue follows a random walk. Let $T_{t}$ be a proportion of $Y_{t}$. Equation (7) predicts that tax rates will be smoothed by means of deficits over time.

Mankiw (1987) [2] assumes that the government finances its expenditure with a mix of direct tax revenue and seigniorage. Suppose the money demand is proportional to the output.

$$
\frac{M_{t}}{P_{t}}=k Y_{t}
$$

where $M_{t}$ is the outside money at time $t, P_{t}$ is the price level at time $t, k$ is a constant. The tax revenue from seignorage is

$$
\frac{\dot{M}_{t}}{P_{t}}=k Y_{t}\left[\frac{\dot{P}_{t}}{P_{t}}+\frac{\dot{Y}_{t}}{Y_{t}}\right]=k Y_{t}(\pi+g)
$$

where $\pi$ is the inflation rate, and $g$ is the growth rate of output. The total tax revenue is defined as

$$
T_{t}=\tau Y_{t}+(\pi+g) k Y_{t}
$$

where $\tau$ is the effective tax rate.

The government minimizes the distortion from direct tax, $f\left(\tau_{t+i}\right)$ and from seignorage $h\left(\pi_{t+i}\right)$ in equation (11) subject to the intertemporal budget constraint (12).

$$
E_{t} \sum_{i=0}^{\infty} \beta^{i}\left[f\left(\tau_{t+i}\right)+h\left(\pi_{t+i}\right)\right] Y_{t}
$$

$$
\sum_{i=0}^{\infty} \beta^{i} G_{t+i}+B_{t}=\sum_{i=0}^{\infty} \beta^{i} T_{t+i}
$$

Three first-order conditions can be derived as follows.

$$
\begin{array}{r}
E_{t} f^{\prime}\left(\tau_{t+i}\right)=f^{\prime}\left(\tau_{t}\right) \\
E_{t} h^{\prime}\left(\pi_{t+i}\right)=h^{\prime}\left(\pi_{t}\right) \\
h^{\prime}\left(\pi_{t}\right)=k f^{\prime}\left(\tau_{t}\right)
\end{array}
$$

Equations (13) coincides with Barro's [1] tax smoothing of optimal fiscal policy. Equation (14) equates the marginal social cost of inflation across time. Equation (15) equates the marginal social costs of the two revenue sources. The tax-smoothing hypothesis can be tested by examining whether the tax rate and the inflation rate have a unit root, respectively. Whether these two tax rates are cointegrated can be used to validate the revenue-smoothing hypothesis.

\section{EMPIRICAL RESULTS}

In this paper, the inflation rate $(I N F)$ is calculated by the changes of consumer price index. The effective tax rate, defined as theratio of tax revenue to GDP $(T A X)$, is considered as a tax variable in the estimation. Fig. 1 depicts these two variables from year 1965 to 2012 . With respect to the tax burden (the ratio of tax revenue to GDP), Taiwan had almost $20 \%$ in the early 1990 s. It fell to $13.9 \%$ in 2008 , relatively lower than that in other OECD countries. In the midst of the 2008 global economic recession, Taiwan government proposed tax cuts in motor vehicle excise tax, corporate and personal income taxes, aiming to stimulate the economy.

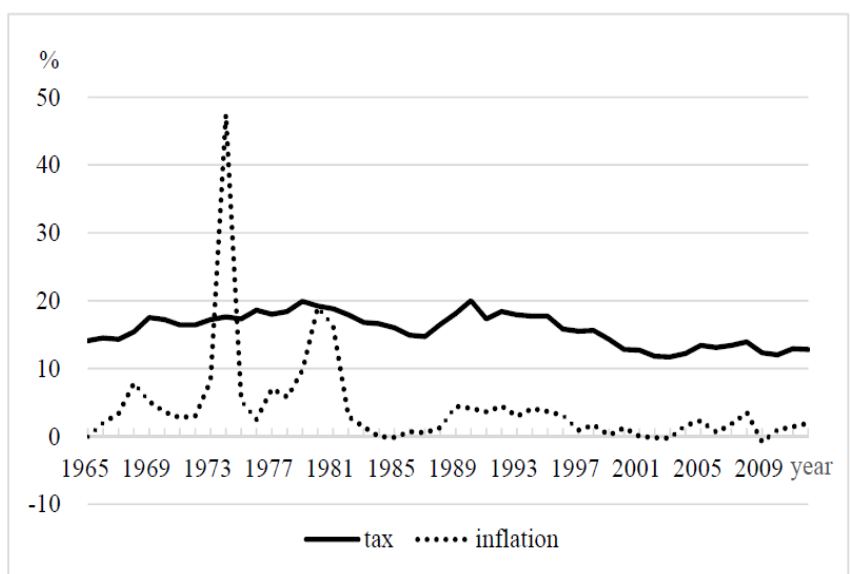

Fig. 1. Inflation and tax revenue as a share of GDP, Taiwan 1965-2012.

Taiwan is a small open economy with scarce natural resources. The domestic producers heavily dependon imported raw materials. In the midst of oil crisis, its inflation rates reached around 47\%. Except for the 1970s, the inflation rates were stably low. The averages of effective tax rates and inflation rates over the 47 years are $15.78 \%$ and $4.22 \%$, respectively.

Table I and Table II present the descriptive statistics and 
correlation coefficients of variables. There are 48 observations in our sample. The correlation coefficient between INFand TAX is around 0.41.

TABLE I: DESCRIPTIVE STATISTICS OF VARIABLES

\begin{tabular}{|c|c|c|c|c|c|c|}
\hline Variable & Name & Mean & Max. & Min. & $\begin{array}{c}\text { Std. } \\
\text { Dev. }\end{array}$ & Obs. \\
\hline TAX & $\begin{array}{c}\text { Tax revenues as a } \\
\text { share of GDP }\end{array}$ & 15.78 & 20.0 & 11.7 & 2.36 & 48 \\
\hline$I N F$ & Inflation rate & 4.22 & 47.45 & -0.86 & 7.44 & 48 \\
\hline
\end{tabular}

TABLE II: CORRELATION COEFFICIENTS OF VARIABLES

\begin{tabular}{c|c|c|}
\hline Variable & $T A X$ & $I N F$ \\
\hline$T A X$ & 1.00 & \\
\hline$I N F$ & 0.41 & 1.00 \\
\hline
\end{tabular}

Prior to conducting cointegration analysis, we need to verify whether the time series are stationary. We report four unit root test results, the augmented Dickey and Fuller (1979, 1981; ADF) [8], [9]; Phillips and Perron (1988; PP) [10]; Elliot, Rothenberg, and Stock's (1996) [11] Dickey-Fuller GLS detrended (DF-GLS); and Kwiatkowski, Phillips, Schmidt, and Shin (1992; KPSS) [12] in Table III. After TAX is differenced once, the hypothesis of unit root is rejected by three tests at the 5\% significance level.The null hypothesis that INFhas a unit root is rejected via PP test at the 5\% significance level.

\begin{tabular}{|c|c|c|c|c|}
\hline Variable & ADF & DF-GLS & PP & KPSS \\
\hline \multicolumn{5}{|l|}{ Levels } \\
\hline TAX & $-2.507(0)$ & $-1.846(0)$ & $-2.507(0)$ & $0.168(5)$ \\
\hline$I N F$ & $-2.674(6)$ & $-1.596(7)$ & $-5.584 * *(4)$ & $0.073(2)$ \\
\hline \multicolumn{5}{|c|}{ First differences } \\
\hline$T A X$ & $-6.465 * *(0)$ & $-6.607 * *(0)$ & $-6.465 * *(1)$ & $0.063(1)$ \\
\hline$I N F$ & $-3.241(6)$ & $-3.117(6)$ & $-29.771(45)$ & $0.343 * *(34)$ \\
\hline
\end{tabular}

Notes: We apply four unit root tests: the augmented Dickey and Fuller (1979; ADF); Phillips and Perron (1988; PP); Elliot, Rothenberg, and Stock's (1996) Dickey-Fuller GLS detrended (DF-GLS); and Kwiatkowski, Phillips, Schmidt, and Shin (1992; KPSS). The numbers in parentheses indicate the selected lag order. The regressions include an intercept and trend. The lag lengths are determined via the Akaike information criterion (AIC) and are in parentheses. The superscript $* *$ indicate significance at the $5 \%$ level. The null hypotheses for all tests except for the KPSS test are unit roots.

We employ Johansen's (1988) [7] maximum likelihood estimation method to examine the long-term relationship between tax revenue as a share of GDP and inflation. The lag length selection is an important issue in the cointegrated vector autoregressive models. Long lag length may cause overparameterization and lead to a loss in efficiency. Short lag length fails to yield white noise residuals and results in estimation bias. We start with a lag length, $k=1$. If the null hypothesis of no serial autocorrelation cannot be rejected, a bigger $k$ is needed until all residuals become white noise. We use the Breusch-Godfrey serial correlation $L M$ test to choose an appropriate lag length. The null hypothesis of no serial correlation is accepted at the $5 \%$ significance level when $k=1$.

After choosing the optimal lag length, we test the number of cointegration relations with Johansen and Juselius's (1990) [13] methodology. The trace and maximum eigenvalue statistics are reported in Table IV. Both statistics indicate at least one cointegration at the 5 percent significance level. This suggests that there is one long-term relationship between inflation rates and effective tax rates.

Equation (16) presents the results of the cointegration coefficients of the long-run relationship equation. At the $5 \%$ significance level, $I N F_{t}$ has a significantly positive effect on $T A X_{t}$. Higher inflation rates are associated with higher tax rates.

$$
T A X_{t}=12.364+0.806 \cdot I N F_{t} .
$$

We further conduct acointegration vector coefficient significance test. Table $\mathrm{V}$ indicates that the effect of inflation on equation (16) is significant at the $5 \%$ level.

TABLE IV: JOHANSEN'S COINTEGRATION TEST FOR TAX AND INF

\begin{tabular}{|c|c|c|c|c|}
\hline \multicolumn{3}{|c|}{$\lambda_{\max }$} & \multicolumn{2}{c}{ TRACE } \\
\hline & statistics & $5 \%$ critical value & statistics & $5 \%$ critical value \\
\hline$r=0$ & $21.421^{* *}$ & 14.265 & $23.519^{* *}$ & 15.495 \\
\hline$r=1$ & 2.099 & 3.841 & 2.099 & 3.841 \\
\hline
\end{tabular}

Notes: $* *$ denotes significance at the $5 \%$ level, and $5 \%$ finite sample critical values are constructed from the asymptotic critical values from Osterwald-Lenum (1992) [14] using the method of Cheung and Lai (1993) [15]. The cointegration rank is $r$.

TABLE V: COINTEGRATION VECTOR COEFFICIENT SIGNIFICANCE TEST

\begin{tabular}{|l|l|}
\hline & $I N F$ \\
\hline$L R$ statistics & $19.303^{* *}$ \\
\hline$p$-value & {$[0.001]$} \\
\hline
\end{tabular}

Notes: LR test statistic is obtained by means of the $\chi^{2}(r)$ test; the figures inside [] are the $p$-values. $* *$ denotes significance at the $5 \%$ level.

\section{CONCLUSION}

This paper examines the tax-smoothing and revenue-smoothing hypotheses with Taiwanese annual data from 1965 to 2012. We conduct Johansen's cointegration technique to investigate the long-run relationship between inflation and tax revenue as a share of GDP. Our results indicate that Taiwanese data are in favor of these two hypotheses. The government may have used seignorage as a supplement to raise tax revenue.

In addition, according to our result, both fiscal policy and monetary policy are implemented in an optimal fashion to finance government expenditure. The government issues debt to finance temporary increases in government expenditure. The budget deficits are accordingly incurred so as to minimize the distortion of taxation.

We regard this paper as a primal research. Further extensionincludes adding additional variables in accordance with Taiwanese data, or employing more advanced econometric techniquesto test these two hypotheses.

\section{REFERENCES}

[1] R. J. Barro, "On the determination of public debt," Journal of Political Economy, vol. 87, pp. 940-971, Oct. 1979.

[2] G. Mankiw, "The optimal collection of seigniorage: Theory and evidence," Journal of Monetary Economics, vol. 20, pp. 327-341, Sep. 1987.

[3] C. H. Huang and K. S. Lin, "Deficits, government expenditures, and tax smoothing in the United States: 1929 - 1988," Journal of Monetary Economics, vol. 31, pp. 317-339, Jun. 1993.

[4] A. Serletis and R. G. Schorn, "International evidence on the tax- and revenue-smoothinghypotheses," Oxford Economic Papers, vol. 51, pp. 387-396, Apr. 1999. 
[5] R. Ricciuti, "Tax smoothing and seigniorage in Italy, 1861-1998," Società Italiana di Economia Pubblica Dipartimento di Economia Pubblica e Territoriale - Università di Pavia, Working Paper , no. 199, 2001.

[6] B. Dogru, "Seignioragerevenue and inflation tax: testing optimal seigniorage theory for Turkish economy," International Journal of Economics and Finance, vol. 5, pp. 122-133, Jun. 2013.

[7] S. Johansen, "Statistical analysis of cointegration vectors," Journal of Economic Dynamics and Control, vol. 12, pp. 231-254, Jun.-Sep. 1988

[8] D. A. Dickey and W. A. Fuller, "Distribution of the estimators for autoregressive time series with a unit root," Journal of the American Statistical Association, vol. 74, pp. 427-431, Jun. 1979.

[9] D. A. Dickey and W. A. Fuller, "Likelihood ratio statistics for autoregressive time series with a unit root," Econometrica, vol. 49, pp. 1057-1072, Jul. 1981.

[10] P. C. B. Phillips and P. Perron, "Testing for a unit toot in time seriesregression," Biometrika, vol. 75, pp. 335-346, Jun. 1988.

[11] G. Elliott, T. J. Rothenberg, and J. H. Stock, "Efficient tests for an autoregressiveunit root," Econometrica, vol. 64, pp. 813-836, Jul. 1996.

[12] D. Kwiatkowski, P. C. B. Phillips, P. Schmidt, and Y. Shin, "Testing the null hypothesis of stationarity against the alternative of a unit root: How sure are we that economic time series have a unit root?" Journal of Econometrics, vol. 54, pp. 159-178, Oct.-Dec. 1992.

[13] S. Johansen and K. Juselius, "Maximum likelihood estimation and inference on cointegration-with applications to the demand formoney," Oxford Bulletin of Economics andStatistics, vol. 52, pp. 169-210, May 1990.

[14] M. Osterwald-Lenum, "A note with quantiles of the asymptotic distribution of the maximum likelihood cointegration rank test statistics," Oxford Bulletin of Economics andStatistics, vol. 54, pp. 461-472, Aug. 1992

[15] Y. W. Cheung and K. S. Lai, "Finite-sample sizes of Johansen's likelihood ratio tests for cointegration," Oxford Bulletin of Economics and Statistics, vol. 55, pp. 313-328, Aug. 1993.

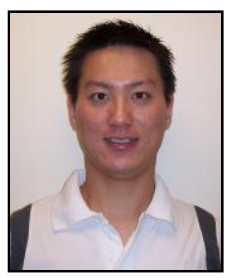

Ming-Hung Yao was born in Taiwan in 1977. He received his B. A. in public finance from the National Chengchi University in 1999. He earned his Ph.D. in economics at Georgia State University in 2007.

$\mathrm{He}$ is now serving as an associate professor in the Department of Wealth and Taxation Management at National Kaohsiung University of Applied Sciences where he joined in 2010 . He has taught principles of economics, public finance, international trade and taxation theory. His current research interests aretaxation policy, public finance, policy analysis, simulation, and forecasting.His papers have been accepted in numerous journals such as the Public Finance Review, International Journal of Electronic Business Management, Journal of Economics and Management, and Journal of Public Administration.

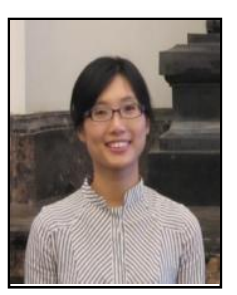

Shiou-Yen Chu is currently an assistant professor in the Department of Economics at National Chung Cheng University. She received her Ph.D. in economics at University of Missouri-Columbia in 2009 and M.A in Public Finance at National Chengchi University in 2003.

Since 2003, she has been a part-time instructorin several universities, including Takming University of Science and Technology (Taiwan), Aletheia University (Taiwan), and University of Missouri-Columbia (USA). After she earned her PhD, she took a position in the Department of Social Sciences at Southwestern Oklahoma State University (USA). Several courses she has taught include principles of macroeconomics/microeconomics (web-based and in-classroom), tax theory, managerial economics (graduate level), and advanced macroeconomics (graduate level). Her current research and teaching interests are monetary economics, international finance, and public economics. 